\title{
Influence of Online Banking on consumer and its perception and acceptance during Covid-19
}

\author{
Jahangir Hameed ${ }^{1}$
}

\begin{abstract}
ne Banking Growth. If service quality/ Technological factors are increased this will result in online banking growth in pandemic situation. Lastly, Social, Cultural and demographic Factors has beta value $-.138, t$-value $=-1.601$ and sig value 0.111 . These values tell that Social, Cultural and Demographic Factors have negative insignificant relationship with Covid19 and Online Banking Growth. Which means if Social, Cultural and Demographic Factors are increased this is result in decreased online banking growth during COVID-19 situation.

Technology has overlapped the globe within the past two decades, from ordering the food through mobile to making sophisticated and high level transactions through e-commerce, everything have been on the fingertips of human being. This enable banking sector to enhnace their services and upgrade their practices to online banking system. This study is about Influence of Online Banking on consumer and its perception and acceptance during Covid-19. Research hypothesis and research questioner had been developed to undertake the study for the research hypothesis, primary data has been used through the sample size and Convenience sampling was carried out where the quota was determined according to the share of the total number. To answer the questions statistically five hypotheses were created and tested through the questionnaire. Results shows that majority of the respondents have agreed and established trust on online banking transactions, their ease with respect to traditional banking, time saving and convenience, while showing a neutral behavior about fraudulent activities.
\end{abstract}

Keywords: Online Banking, Customer Satisfication, Technolgical Factor, Demographic, Covid-19.

\section{Introduction}

Online banking has been the top most recent advancement which enables customers with shopping, fund transfers and many more, all through online platform. Online banking has made it easy for people as they donot need to stand in ques and wait for hours. One can have access of all banking records and ifnormation $24 / 7$ within reach through online banking system. People can carry out online transactions; sending and recievieng amount with surity of clearance mainly at their homes. If one has perosnal computer or mobile devies, it becomes easy for him to engulf in the handy process of online banking system. Today in the modern world, people has given different attributes to online banking such as electronic, web, internet or mobile banking. Online banking is a connectivity channel between customers and benefactors.

For the purpose of online banking different banks across the globe have estbalished applications and websites through which online banking could be taken place. These online and web based

${ }^{1}$ Karachi University Business school / jhangirhameed@gmail.com 
forms on banking has facilitated the customers with the best possible ways. Through online banking cost of human resources has reduced. We can say that online banking system has helped banks to gain favour from their customers with imporved services and revise tradional methoda of banking. Globally, there is a surge in investment as a result of online baking system and different banks have facilitated their customers with huge profits. This modern way of banking is possible when customers comply with the technological advanment in field of banking.

As far as online banking is concerned in Pakistani context, its scope seems not so high as people are still not fimilari of modern ways of banking. The aim of this research is to investigate acceptance of Online banking in Pakistan on consumer perceptions and its acceptance. The study was limited in in scope because of Covid-19. The major objective of the study was to investigate acceptance of online banking in Pakistan during covid-19. The major influences on this relationship were security and privacy issues, peoples lack of knowledge, problem in accessing internet, satisfaction of customers, adaptation of modern technology, socio-cultural influences including Islamic and traditional values along with demographic representations.

To validate the objective of research, we have used Research hypothesis and research questioner. For the research hypothesis, we used primary data from data collection. Primary Data is also collected through the sample size of and was chosen based on sources. Convenience sampling was carried out where the quota was determined according to the share of the total number. To answer the questions statistically five hypotheses were created and tested through the questionnaire. The major research instrument from which we decide whether our business research hypothesis is accepted or not for that we collect data through questioner.

\section{Problem Statement}

In traditional banking people sometimes pay more amount on transactions than the actual amount being deposited or withdrawn. They have to stand for hours in banks to get their transactions done. Online or web/app-based banking system has facilitated customers to carry out economic and secure banking. In modern developing world various banks has shifted from traditional to online systems which turned out be beneficial for customers saving time reducing the cost. Also, technology is user friendly which has enabled users to use it in abundance. According the user and customers perspective online banking is customer oriented which is accessible $24 / 7$ to the customers.

With the rampant use of online banking there are some hurdles as well. People are observed with lack of awareness about technology, they have difficulty in operating online system, they have legal issues, fragile relation between banker and customers. According to some people online banking is customer oriented and safe but for other people in Pakistan who comes from rural areas it is very challenging. They have lack of awareness, security threats and difficulty in access. Therefore, it becomes significant to investigate perception of Pakistani people towards acceptance of online banking. 


\section{Study Objectives}

The Primary Objective of this study is to find out the level of impact of online banking on consumer behavior and its perception during covid-19 through customer satisfaction, technological factors, social, cultural, economic and demographic factors.

\section{A Secondary Objective}

The objective is to identify the usage of online during covid-19.

The objective is to identify what kind of barriers and resistance occurs on consumer mind for online banking

The objective is to identify how we can improve online growth in Pakistan.

\section{B Scope of Study:}

The scope of the study is to discover the acceptance of Online banking in Pakistan on consumer perceptions. The scope of the research was limited Due to the Pandemic situation. The objective of the research was to find acceptance of online banking in Pakistan during covid-19. The major factors affecting this relationship were congruency to the awareness and information marketed by banks, security issues, privacy issues, demographic factors etc.

\section{Hypothesis}

H1: Trust, Security, and privacy issue among the acceptance of Online banking customers in Pakistan.

H2: Customer Satisfaction influence the acceptance of Online banking among banking customers in Pakistan.

H3: Economic factors and demographicfactors are one of the challenges for implementation and development of Online banking in Pakistan.

H4: Management and banking issues are one of the challenges for implementation and development of Online banking in Pakistan.

H5: Technological, Social, and culturalbarriers are one of the challenges for implementation and development of Online banking in Pakistan.

\section{$4 \quad$ Literature Review}

The literature suggests that many factors influence the acceptance and consumer perception of online banking during pandemic. Different authors suggest different opinions about adoption of online banking system in a country.

In internet banking privacy and security plays a vital role. If these both factors are provided to customers than it increases comfort of customers towards the bank. Privacy and protection of 
online banking transactions and confidentiality of personal information are critical interest to both internet banking customers and the banking industry. Aladwani (2001) Online banking analysis, prospective clients have classified internet security and consumer privacy as the most imperative potential problems faced by banks. In studies of banking, the importance of security and confidentiality to the acceptance of online banking has been specified. (Roboff and Charles, 1998; Sathye, 1999; Hamlet and Strube, 2000; Tan and Teo, 2000; Polatoglu and Ekin, 2001; Black et al., 2002; Giglio, 2002; Howcroft et al., 2002). Roboff and Charles (1998) discovered that, despite their knowledge of the risks and their dependence on their bank on privacy issues, individuals have a fragile understanding of online banking security risks. Similarly (Fatima Mazhar, 2014) studied the impact of various factors on the adaptation of online banking through TAM (technological acceptance model) in Pakistan, specifically in non-urban regions

More precisely, Privacy and protection were found to be crucial barriers to the adoption of online banking, several studies have shown that protection and privacy are important indicators of the desire towards online banking (Yousafzai et al., 2009; Abu-Shanab \& Abu-Baker, 2011). This mindset indicates that Internet banking networks can have protection measures and reduce the possibility of leakage of user-related information leading to scam (Ameme, 2015).

(Mohammad Alafeef, 2012) claims that, most talked external factor that is considered to be an obstacle for adaptation of technology is trust, and believes that people will live upto his expectations and will not take advantage of it, McGoldrick and Laforet explains that possible reason for people to not go for adaptation of technology or online banking are privacy and security concerns. Peralta and Novak (1999) says issues such as security fear, fear of invading private information, less profitable business, less security for payment are all obstacles in way of online banking's adaptation. In lessening these concerns, plays a crucial role. It helps to reduce financial transaction-related complexities, ambiguities, threats and fraud, thus increasing the probability that customers will go for online banking.

According to (Syed Sheheryar Ali Kazmi, March 2015) has defined issue and challenges that Pakistan facing on online banking sector. First current issue is lack of infrastructure investment in Information technology, mostly banks in Pakistan still behind from other countries banks they have not adopt data base system or integration of enterprise software like SAP and oracle which is also a big cause towards digitization of e-banking in Pakistan , similarly issue like trust issue of customer towards e-banking, security and privacy issue which is causing cyber-attack on online banking also a big obstacle in adoption of online banking in Pakistan.

Other major issue like money laundering which is also facing by banks because it's easy to hack the account and transfer the payment to other accounts of person it occurs due to the lack of basic infrastructure of Information technology systems and untrained staff of banking industry which is also a big barrier facing by banks in Pakistan.

In marketing major concern is satisfaction of the customers (Safeena R, 2015) . it increases the purchase and attutides of the customers such as repetition and loyality to the brand. According to Oliver (1980), when clients equate their understanding of real brand results with expectation, the sense of satisfaction emerges. A variety of concepts have been reported on consumer 
satisfaction. . Oliver (1980) describes satisfaction as an emotional evaluative decision about a good or service after consumption. Similarly, Tse and Wilton (1988) identified consumer satisfaction as a "customer reaction to the evaluation of the potential difference between expectations and end result after usage." Gratification can also be defined as the evaluation of a post-purchase evaluation of the quality of certain service/product and compared to the expectation of previous purchase Kotler \&Keller (2011)

According to the studies so far consumers sense of satisfaction is displayed in cusomers attitude to adopt the platform of online banking be it internet banking, or mobile banking.

(Jamil Hammoud, 2018) reveals in his research that demographics influences are also associated wih adoptation of online banking. Accoridng to one study conducted in US, which suggests that online banking is affected by level of education and income postivelty and being affected negatively due to age.Rogers (1995) says that young generation with high skills and knowledge are more inclined to adopt techonoligcal advancements and new methods. Also genders seems to affect online banking directly. Income level also determine the adoption of online banking people with more stable income have more use as compare to low income level customers. Then the lack of investment in banking sector specifically in the area of online banking facilities and ongoing economic crisis also the barriers in acceptance of online banking in Pakistan.

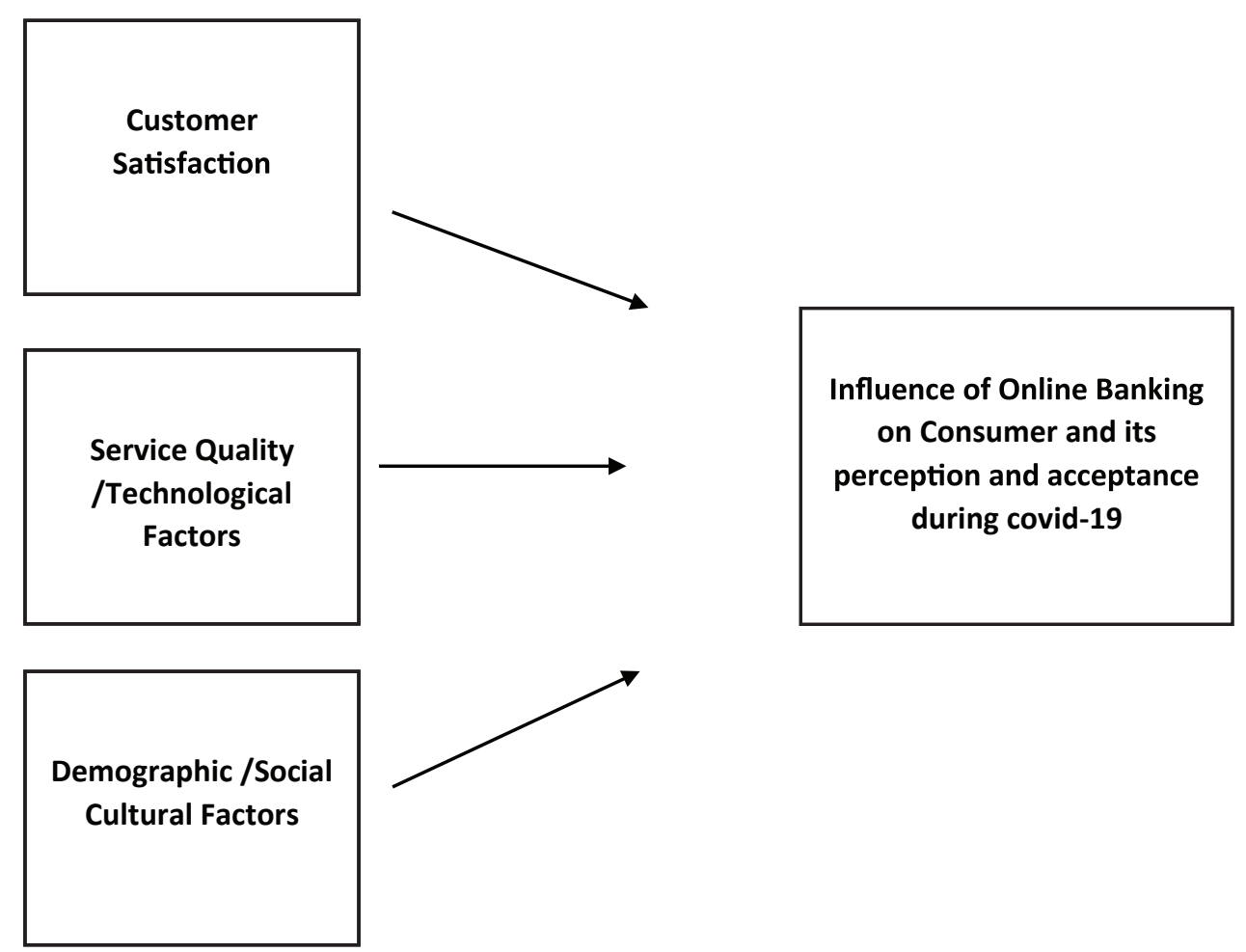

Figure 1: Theoretical Framework:

The Covid-19 is an independent variable in the study and its impacting the influence of online banking. Customer Satisfaction, Service quality, technological factors, social cultural factors and demographic factors are dependent variables in the present study. However as per the literature 
of the study, it has been observed that covid-19 its affected consumer business and each sector adversely because of the pandemic and there is no prediction related to it.The pandemic majorly impacting countries' economies and as well customer income is affected. On the other hand, covid-19 has also emerged an opportunity for online industries like e-commerce and online banking has growth enormously in this pandemic around the world.

\section{$5 \quad$ Banking Channels Review}

As per the SBP Apr-June quarterly data on alternative delivery channels of banks (ADC) for banking payment sector payments and transactions.

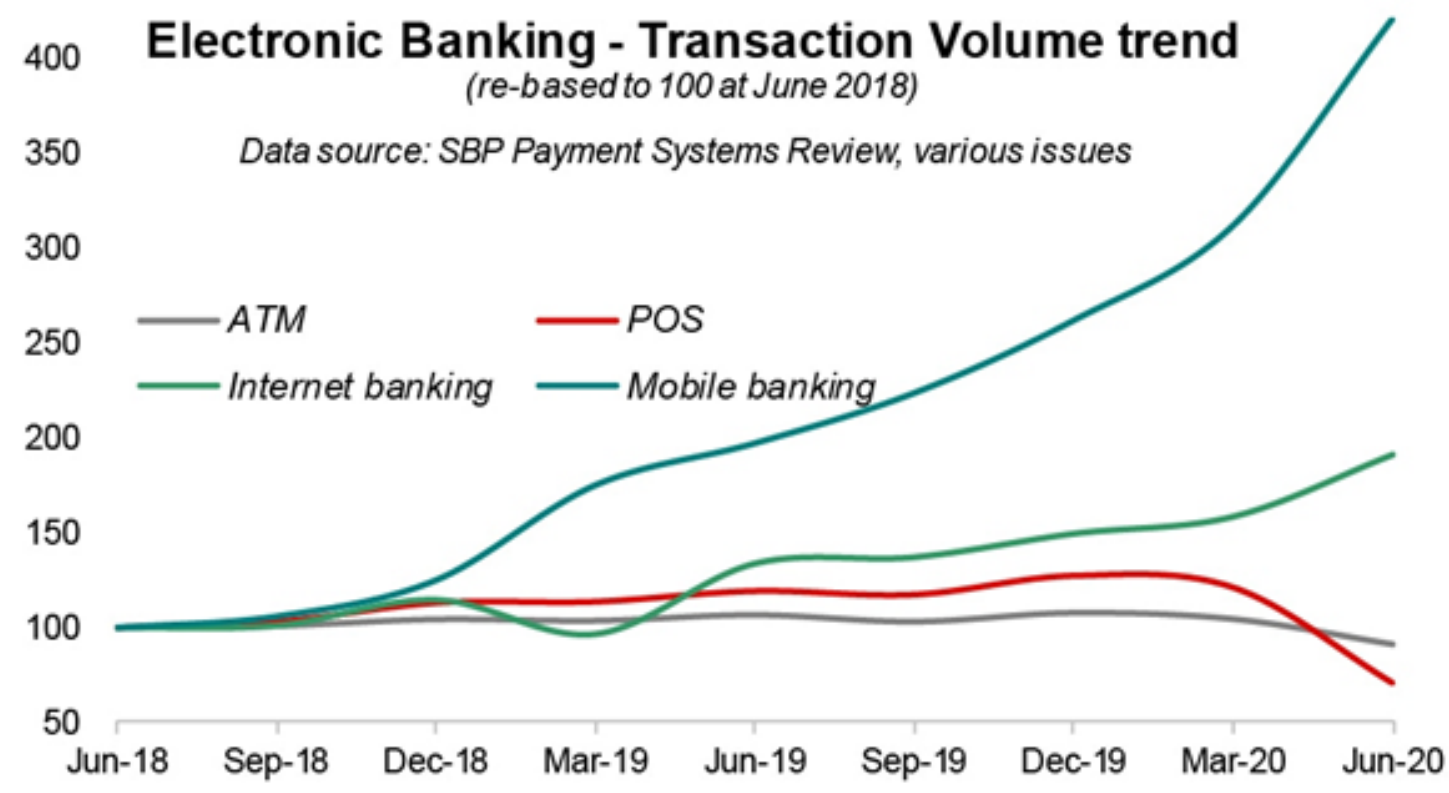

Figure 2: Electronic Banking - Transaction Volume Trend

As per figures it is observed ATM cash withdrawal during pandemic is going down due to the lockdown and pandemic situation but on the other hand mobile banking channels has been growing well in recent year and the register mobile banking transactions had reached 8.5 million as of June 2020 with 50 percent growth in just a year of 2020 ,some 27 banks has offering this ADC.The mobile banking momentum continued amidst the lockdowns. For instance, transaction volume of 29 million in Apr-Jun was higher by a third on quarterly basis and it more than doubled on a yearly basis. The transaction value of Rs622 billion in the same quarter followed similar levels of quarterly and yearly spikes. There is continued growth across the board, but mostly in intra-bank and inter-bank fund transfers

The third pillar of e-banking is internet banking, which is another fast-growing ADC, offered by 28 banks to nearly 4 million users as of June 2020 . The lockdowns had accelerated the growth in this channel relative to recent quarters. At 17 million transactions in Apr-Jun, the volume was higher 21 percent over previous quarter and up 43 percent year-on-year. At Rs894 billion, the 
transaction value in the corona quarter was 20 percent and 64 percent higher on quarterly and yearly bases, respectively. Just as with mobile banking, fund transfers take the lead in expanding transaction pie for internet banking.

And finally, the ever-shrinking POS machines, which had reduced by 14 percent year-on-year to 49,000 as of June 2020 and embraced by mere 9 banks. The pandemic quarter's troubles have set back quarterly POS transactions even more than two years. The lockdown did not help and customer are afraid to use POS machine Due to pandemic mutation.

This analysis show that some ADC channel growth has been decreases and some of ADC channels like mobile and internet banking has tremendously growth during pandemic which is good signed for banking sector growth.

\section{$6 \quad$ Methodology}

\section{A Research Philosophy}

In view of Silverman (2016), research philosophy is the first step of methodology as it creates the base of the data collection, extraction, and process. Through this, researchers explore the possibilities of systematically gathering information from different sources to systematically complete study objectives and questions. Some of the research philosophies are positivism, realism, and interpretivism as it provides structure to study. Interpretivism philosophy supports the qualitative study, and it allows researchers to extract detailed information. However, realism philosophy is critical because these objectives are related to the real event, and researchers need to capture data from authentic sources.

For the present study, information has been derived from positivism philosophy as it supports quantitative research, and in this, the researcher capture data from numerical sources. The researcher derives information from a quantitative source as it allows the researcher to measure the relationship among variables with the help of software to derive results accurately.

\section{B Approach}

In view of Gray (2016), deductive and inductive are approaches of study, and they are connected with the philosophy of research and further allow analyst to derive data from accurate sources. According Taylor ml (20 IS), the inductive approach supports interpretivism philosophy, and in this, detailed information is extracted. This approach is considered because it is one of the flexible sources and allows researchers to derive information from multiple ways in detail. In an inductive approach, an analyst emphasizes specific observation, and as per that, they derive information in detail to complete the study effectively.

However, in this study, the researcher focuses on the deductive approach because it supports positivism philosophy y and it is captured through the quantitative source. The deductive method has a complete structure that is being followed by researchers globally; it starts with a hypothesis of the study, and further information is collected to accept or reject it as per sources. However, quantitative data provide numerical data, which helps in concluding results and allow 
the researcher to gather knowledge about the relationship among variables and complete findings effectively.

\section{Data Collection Method}

In view of Gray \& Alins (2016), primary and secondary are data collection methods that researchers consider completing the study systematically and fulfill the requirements of objectives effectively. The primary techniques provide more specific information because, in this, first-hand knowledge is gathered, which is related to a study. However, secondary sources are considered to get detailed information, and it helps to complete the literature of research.

In this study, the researcher adopted both methods to complete the study because the analyst mainly needs to capture information related to re-education of online banking influence during Covid-19 and for that data is required, and secondary data further complete the requirement of literature. The secondary information has been derived from books, literature, researchers, journal, articles, and other online sources to get the authentic information. For the primary source, the questionnaire has been considered by the researcher to capture information from customers as they are people who use the Online banking from different parts backgrounds.

\section{Sample Size and Technique}

According to Martens (2014), the sample size of a stud y is one of the critical things as it needs to be selected with complete concentration because it impacts the research findings. The study sample size of the study is 250 as it presents the opinion of all customers includes students, businessman, job-oriented peoples etc. However, as per opinion of Creswell (2014), two sampling techniques are commonly considered by researchers, which are probability and non-probability. The probability y-sampling techniques are simply random, random cluster, and systematic sampling.

In the current study, the researcher has been adopted non-probability sampling because the analyst does not have information about the total population. When the researcher does not exact information about the population non-probability sampling technique is considered, and from further techniques, the Convenience sampling method is adopted. Through Convenience sampling, the researcher can judge people and gather information from people who use online banking during covid-19 or before pandemic as well.

\section{E Ethical consideration}

In view of Worthington and Bodie (2017), ethics of the study are considered by researchers because it has an impact on the findings and credibility of the stud y. In this research, numerous ethics are considered because they can affect conclusions and allow the researcher to systematically complete the study. The researcher provides credit to the study authors and derives information from authentic sources to enhance credibility. Further, the researcher does not manipulate any data from primary and secondary sources to maintain the findings' integrity. However, respondents are part of the study and the researcher respected each individual, and information has not been derived forcefully. The researcher derived information from customers 
and treated them anonymously as they were not willing to share personal information, which is part of the study's ethics.

\section{$7 \quad$ Result}

This chapter summaries the analysis or the result generated. SPSS was used to assess the data. Regression analysis, correlation analysis, reliability and descriptive analysis was used to analyze data.

\section{A Reliability}

Table 1: Reliability Statistics

\begin{tabular}{cc} 
Cronbach's Alpha & N of Items \\
.903 & 17 \\
\hline
\end{tabular}

Above table tells about the reliability and internal consistency of the instrument. Table tells that the value of Cronbach's Alpha is .903. Acceptable range of Cronbach's Alpha is 0.7 to 0.9. As the value of instrument is equal to 0.9 this mean

That instrument used is acceptable and reliable and can be used to research. 0.9 value of instrument reliability tells that instrument used is highly reliable.

Descriptive Analysis:

Table 2: Descriptive Statistics

\begin{tabular}{lllllc} 
& N & Minimum Maximum & Mean & $\begin{array}{c}\text { Std } \\
\text { Deviation }\end{array}$ \\
Customer Satisfaction & 260 & 1 & 5 & 3.82 & .675 \\
\hline Service Quality/Technological Factors & 260 & 1 & 5 & 3.73 & .682 \\
\hline Social, Cultural and Demographic Factors & 260 & 1 & 5 & 3.80 & .646 \\
\hline Covid19 and Online Banking Growth & 261 & 1 & 5 & 3.62 & .828 \\
\hline Valid N (listwise) & 260 & & & & \\
\hline
\end{tabular}

Descriptive analysis is used to find out the distribution of the data. It also tells about the correlation of variables. Its summaries the data, however it cannot be used to draw any conclusion. The above table tells that responses collected or used in this research are 260; N=260. Similarly, it tells the mean of variables and from the above it can be seen that all variables have mean values close to each other. Standard deviation tells about the skewness of the data which is how much your data is spread. The greater value of standard deviation shows that data is greatly spread. However, from the above table it can be seen that descriptive analysis doesn't contain higher values of SD which means our data is not very much spread. 


\section{B Correlation Analysis}

Table 3: Correlations

\begin{tabular}{|c|c|c|c|c|c|}
\hline & & $\begin{array}{l}\text { Customer } \\
\text { Satisfaction }\end{array}$ & $\begin{array}{l}\text { Service Quality/ } \\
\text { Technological } \\
\text { Factors }\end{array}$ & $\begin{array}{l}\text { Social, Cultural } \\
\text { \& Demographic } \\
\text { Factors }\end{array}$ & $\begin{array}{l}\text { Covid19 and } \\
\text { Online Banking } \\
\text { Growth }\end{array}$ \\
\hline & Pearson & 1 & $.650 * *$ & $.707^{* *}$ & $.549 * *$ \\
\hline Customer & Correlation & & & & \\
\hline \multirow[t]{2}{*}{ Satisfaction } & Sig. (2-tailed) & & .000 & .000 & .000 \\
\hline & $\mathrm{N}$ & 260 & 260 & 260 & 260 \\
\hline $\begin{array}{l}\text { Service } \\
\text { Quality/ }\end{array}$ & $\begin{array}{l}\text { Pearson } \\
\text { Correlation }\end{array}$ & $.650^{* *}$ & 1 & $.880^{* *}$ & $.879^{* *}$ \\
\hline Technological & Sig. (2-tailed) & .000 & & .000 & .000 \\
\hline Factors & $\mathrm{N}$ & 260 & 260 & 260 & 260 \\
\hline Social, & Pearson & $.707^{* *}$ & $.880^{* *}$ & 1 & $.747 * *$ \\
\hline Cultural and & Correlation & & & & \\
\hline Demographic & Sig. (2-tailed) & .000 & .000 & & .000 \\
\hline Factors & $\mathrm{N}$ & 260 & 260 & 260 & 260 \\
\hline $\begin{array}{l}\text { Covid19 and } \\
\text { Online }\end{array}$ & $\begin{array}{l}\text { Pearson } \\
\text { Correlation }\end{array}$ & $.549^{* *}$ & $.879 * *$ & $.747 * *$ & 1 \\
\hline Banking & Sig. (2-tailed) & .000 & .000 & .000 & \\
\hline Growth & $\mathrm{N}$ & 260 & 260 & 260 & 261 \\
\hline
\end{tabular}

**. Correlation is significant at the 0.01 level (2-tailed).

Correlation matrix is used to evaluate the relationship between variables. It not only tells about the relationship between independent variable and dependent variable but it also tells about the relationship among independent and dependent variables. It helps to conclude it variables have significant relationship or not. Above table depicts that customer satisfaction has significant relationship with all variables used in the research. Since the sig value of all variables used to determine their relationship with customer satisfaction is 0.000 . Moving on if we analyze the relationship of Service Quality/ Technological Factors with rest of the variables, this can be concluded that Service Quality/ Technological Factors have significant relationship with other factors as the sig value of all variables is 0.000. Similarly, table tells that Social, Cultural and Demographic Factors have significant relationship with other variables; sig value of these variables is 0.000 . Finally, if we evaluate the relationship of dependent variable which is COVID 19 and online banking growth, it can be said that dependent variable has significant relationship with independent variables as the sig value of all independent variables is 0.000 . 


\section{Regression Analysis}

Table 4: Model Summary

\begin{tabular}{lcccc} 
Model & R & R Square & Adjusted R Square & $\begin{array}{c}\text { Std. Error of the } \\
\text { Estimate }\end{array}$ \\
1 & $.881 \mathrm{a}$ & .776 & .774 & .395 \\
\hline
\end{tabular}

a. Predictors: (Constant), Social, Cultural and Demographic Factors, Customer Satisfaction, Service Quality/Technological Factors

Model summary tells about model fit. It tells about the strength of relationship of dependent variable and model of the study. $\mathrm{R}$ value depicts the strength of relationship. The greater the value of $R$, the stronger the relationship. $R$ value of the model is .881 which shows that model has strong relationship with dependent variable. $R$ square which is coefficient of determination indicates the total variation in dependent variable is explained by independent variable. Here the value of R-Square is .776 which means that $77.6 \%$ of the total variation is explained by independent variables rest is explained by unknown factors.

Table 5: ANOVA ${ }^{\mathrm{a}}$

\begin{tabular}{llccccc} 
Model & Sum of Squares & df & Mean Square & F & Sig. \\
\cline { 2 - 7 } 1 & Regression & 138.396 & 3 & 46.132 & 295.926 & $.000 \mathrm{~b}$ \\
\cline { 2 - 7 } & Residual & 39.908 & 256 & .156 & & \\
\cline { 2 - 7 } & Total & 178.304 & 259 & & & \\
\hline
\end{tabular}

a. Dependent Variable: Covid19 and Online Banking Growth

b. Predictors: (Constant), Social, Cultural and Demographic Factors, Customer Satisfaction, Service Quality/Technological Factors

One of the most important table in regression analysis is ANOVA because it tells if the model is significant or not. In above table the F value of model is 295.926. As per researchers F value should be greater. The greater value of $\mathrm{F}$ results in more accurate result. Above table tells that our mode is significant as the sig value is 0.000 .

Table 6: Coefficientsa

\begin{tabular}{|c|c|c|c|c|c|c|}
\hline \multirow[t]{2}{*}{ Model } & & \multicolumn{2}{|c|}{$\begin{array}{c}\text { Unstandardized } \\
\text { Coefficients }\end{array}$} & $\begin{array}{c}\text { Standardized } \\
\text { Coefficients } \\
\end{array}$ & \multirow[t]{2}{*}{$\mathbf{t}$} & \multirow[t]{2}{*}{ Sig. } \\
\hline & & B & Std. Error & Beta & & \\
\hline \multirow{4}{*}{1} & (Constant) & -.246 & .156 & & -1.580 & .115 \\
\hline & Customer Satisfaction & -.016 & .052 & -.013 & -.317 & .752 \\
\hline & $\begin{array}{l}\text { Service Quality/ } \\
\text { Technological Factors }\end{array}$ & 1.195 & .076 & .982 & 15.747 & .000 \\
\hline & $\begin{array}{l}\text { Social, Cultural and } \\
\text { Demographic Factors }\end{array}$ & -.138 & .086 & -.107 & -1.601 & .111 \\
\hline
\end{tabular}

a. Dependent Variable: Covid19 and Online Banking Growth 
Coefficient table tells about the significance, strength and positive or negative relationship of independent variables with dependent variables. From above table it can be seen that customer satisfaction has insignificant negative relationship with Covid19 and Online Banking Growth as the sig value is greater than 0.752 , and $t$ vale is -3.17 . In order to accept the significance of hypothesis, Sig value should be less than 0.05 and $t$ value should be more than 2 . Therefore, it can be said that customer satisfaction doesn't have any impact on Covid19 and Online Banking Growth. Moving on to service quality/ Technological factors, the beta value is 1.195, t- value is 15.747 and sig value is 0.000 , this means that service quality/ Technological factors has positive significant relationship with Covid19 and Online Banking Growth. If service quality/ Technological factors are increased this will result in online banking growth in pandemic situation. Lastly, Social, Cultural and demographic Factors has beta value -.138 , t-value $=-1.601$ and sig value 0.111. These values tell that Social, Cultural and Demographic Factors have negative insignificant relationship with Covid19 and Online Banking Growth. Which means if Social, Cultural and Demographic Factors are increased this is result in decreased online banking growth during COVID-19 situation.

\section{Conclusion and Recommendation}

In view of Hansol (2020) Covid-19 badly effected on all business and consumer purchasing power and its long term risk is still continue in the world .Most of Analysis and Experts do not have complete information to covid-19 consequences on economy growth and its impact on industries .In the light of Primary source it has been observed that majority of participants use online banking on going Covid-19 pandemic ,It is found from a Secondary source( Business Recorder) the Annual Banking Channels Review 2020 the technology has given edge on banking operation during pandemic customers can effectively perform transaction through ADC channels which includes online banking and dramatically increasing day by day as compare to 2019 .On the other hand as per Sneader and Singhal (2020) consumer behavior change drastically, and they are less likely to spend on luxurious goods and more likely to essential ,similarly some customer are willing to live everyday life with pandemic situation and some are waiting for vaccine to start their life as usual in the past years .

Furthermore, as per survey results, most of the respondents agree that due to covid -19 they prefer to use online banking over the traditional banking channels. In conclusion, research suggests that online banking is choice of many customers because it appears to be favorable for them because of its worth, consumer satisfaction, advanced technology, security measures and privacy concerns. Besides these other influences on the acceptance of online banking are its advertisement that provided sufficient information to the customers through electronic and print media.

It has been discovered that around 64\% people turned towards online banking. Online banking was accepted by Pakistani people owing to its usefulness and ease, still there is room for improvement as some people are unsure about online banking and its security so the benefactors need to put efforts to encourage people for online banking. Further researchers may conduct their study on online banking in relation to demographics factors including education level of the consumers. Decisions could be made on behalf of bank managers for expansion of market considering the usefulness, security and privacy in the online banking system. 


\section{References}

[1] Fatima Mazhar, S. I. (2014). An Investigation of Factors Affecting Usage and Adoption of Internet \& Mobile Banking In Pakistan. International Journal of Accounting and Financial Reporting.

[2] Jamil Hammoud, R. M. (2018). The Impact of E-Banking Service,Quality on Customer Satisfaction: Evidence from Leabanese Banking Sector. SAGE Open.

[3] Mohammad Alafeef, D. S. (2012). The Influence of Demographic Factors and User Interface on Mobile Banking Adoption. Journal of Applied Sciences.

[4] Safeena R, A. D. (2015). Case study on internet banking. Journal of Internet Banking and Commerce .

[5] Stacy L Wood. (2012 Volume 78, Issue 1,). Future fantasies: a social change perspective of retailing in the 21st century. Journal of Retailing, 77-83.

[6] Syed Sheheryar Ali Kazmi, M. H. (March 2015). E-Banking in Pakistan: Issues and Challenges. International Journal of Academic Research in Business and Social Sciences.

[7] Business Recorder Pakistan. (2020, ocotber 16). E-banking during pandemic. p. 1.

[8] Silverman, D. (2017). How was it for you? The Interview Society and the irresistible rise of the (poorly analysed) interview. Qualitative Research, 17(2), 144-158.

[9] Gray, C., \& Malins, J. (2016). Visualizing research: A guide to the research process in art and design. Routledge.

[10] Mertens, D. M. (2014). Research and evaluation in education and psychology: Integrating diversity with quantitative, qualitative, and mixed methods. Sage publications.

[11] Sudarsono, H., Nugrohowati, R. N. I., \& Tumewang, Y. K. (2020). The Effect of Covid-19 Pandemic on the Adoption of Internet Banking in Indonesia: Islamic Bank and Conventional Bank. The Journal of Asian Finance, Economics, and Business, 7(11), 789800 .

[12] Hwang, H., Hur, W. M., \& Shin, Y. (2020). Emotional exhaustion among the South Korean workforce before and after COVID-19. Psychology and Psychotherapy: Theory, Research and Practice.

[13] Sneader, K., \& Singhal, S. (2020). Beyond coronavirus: The path to the next normal. McKinsey \& Company.

[14] Qureshi, T. M., Zafar, M. K., \& Khan, M. B. (1970). Customer acceptance of online banking in developing economies. The Journal of Internet Banking and Commerce, 13(1), 1-9.

[15] Oldekop, J. A., Horner, R., Hulme, D., Adhikari, R., Agarwal, B., Alford, M., \& Bebbingi on, A.J. (2020). COV ID- 19 and the case for global development. Wr»/d Dry rkıymrnt, 134,

[16 Vernirnrnen, P., Quiry, P., Dallocchio, M., Le Fur, Y., \& Salvi, A. (2014). C'r»pr» err \{incur r.'thror $v$ and yrn rim r. John Wile y \& Sons. 
[17] Worthington, D.L. and Bodie, G.D. eds., (20 17). Thr .tr>orr r6ook rıf listrninz rrsrii «h.' Mrth«Holog v urm mrosurrs. John Wile y \& Sons.

[18] Deloitte (2020) . Impact of COV ID- 19 to the Banking Sector. Retrieved from https:// www2.deloitte.com/cn/en/pages/risk/articles/covid-19-impact-on-banks.html

[19] Dietrich, A., Keuster, K., Muller, G. J., \&Schoenle, R. (2020). News and uncertaint y about covid- 19: Survey evidence and short-run economic impact.Unirri:tirv $r \backslash\{$ T'ofiingrn. Retrieved from<http://people.brandeis.edu/-schoenle/research/COVlD19 March2020. pdf>

[20] Flogel, F., \& Gartner, S. (2020). The COVID-19 Pandemic and Relationship Banking in Germany: Will Regional Banks Cushion an Economic Decline or is A Banking Crisis

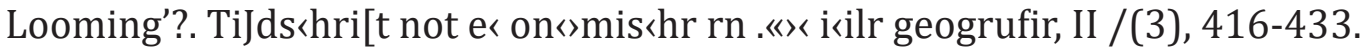

